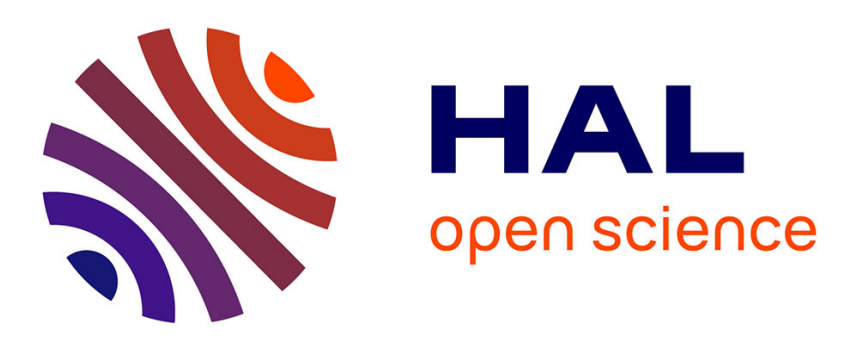

\title{
Attenuation of cue-induced reinstatement of nicotine seeking by URB597 through cannabinoid CB1 receptor in rats
}

Benoit Forget, Mihail Guranda, Islam Gamaleddin, Steven R. Goldberg, Bernard Le Foll

\section{To cite this version:}

Benoit Forget, Mihail Guranda, Islam Gamaleddin, Steven R. Goldberg, Bernard Le Foll. Attenuation of cue-induced reinstatement of nicotine seeking by URB597 through cannabinoid CB1 receptor in rats. Psychopharmacology, 2015, 233 (10), pp.1823-1828. 10.1007/s00213-016-4232-y . hal-01573514

\author{
HAL Id: hal-01573514 \\ https://hal.science/hal-01573514
}

Submitted on 10 Aug 2017

HAL is a multi-disciplinary open access archive for the deposit and dissemination of scientific research documents, whether they are published or not. The documents may come from teaching and research institutions in France or abroad, or from public or private research centers.
L'archive ouverte pluridisciplinaire $\mathbf{H A L}$, est destinée au dépôt et à la diffusion de documents scientifiques de niveau recherche, publiés ou non, émanant des établissements d'enseignement et de recherche français ou étrangers, des laboratoires publics ou privés. 


\title{
Attenuation of cue-induced reinstatement of nicotine seeking by URB597 through cannabinoid $\mathrm{CB}_{1}$ receptor in rats
}

\author{
Benoit Forget $^{1,2} \cdot$ Mihail Guranda $^{1} \cdot$ Islam Gamaleddin $^{1,3}$. \\ Steven R. Goldberg ${ }^{4} \cdot$ Bernard Le Foll $^{1,5,6}$
}

Received: 3 September 2015 / Accepted: 31 January 2016 / Published online: 11 February 2016

(C) Springer-Verlag Berlin Heidelberg 2016

\begin{abstract}
Rationale The endocannabinoid system is composed of endocannabinoids (such as anandamide), their target receptors ( $\mathrm{CB}_{1}$ and $\mathrm{CB}_{2}$ receptors, $\mathrm{CB}_{1} \mathrm{Rs}$ and $\mathrm{CB}_{2} \mathrm{Rs}$ ), the enzymes that degrade them (fatty-acid-amide-hydrolase (FAAH) for anandamide), and an endocannabinoid transporter. FAAH inhibition has been recently identified as having a critical involvement in behaviors related to nicotine addiction and has been shown to reduce the effect of nicotine on the mesolimbic dopaminergic system via $\mathrm{CB}_{1} \mathrm{R}$ and peroxisome proliferatoractivated receptor alpha (PPAR $\alpha$ ). Thus, inhibition of FAAH may represent a novel strategy for smoking cessation, but its
\end{abstract}

In memoriam of Steven R. Goldberg

Bernard Le Foll

bernard.lefoll@camh.ca

1 Translational Addiction Research Laboratory, Campbell Family Mental Health Research Institute, Centre for Addiction and Mental Health, CAMH, 33 Russell Street, Toronto, ON, Canada M5S 2S1

2 Institut Pasteur, Unité de Neurobiologie Intégrative des Systèmes Cholinergiques, CNRS UMR 3571, 75724 Paris Cedex 15, France

3 Institute of Environmental Studies and Research, Ain Shams University, Cairo, Egypt

4 Preclinical Pharmacology Section, Behavioral Neurosciences Branch, Intramural Research Program, NIDA, NIH, DHHS, Baltimore, MD, USA

5 Alcohol Research and Treatment Clinic, Addiction Medicine Services, Ambulatory Care and Structured Treatments, CAMH, Toronto, ON, Canada

6 Departments of Family and Community Medicine, Pharmacology, Psychiatry, Institute of Medical Sciences, University of Toronto, Toronto, ON, Canada mechanism of action on relapse to nicotine seeking is still unknown.

Objective The study aims to explore the mechanism of action of the inhibitor of FAAH activity, URB597, on relapse to nicotine seeking by evaluating the effect of the $C_{1} R$, $\mathrm{CB}_{2} \mathrm{R}$, and PPAR $\alpha$ antagonists on the attenuating effect of URB597 on cue-induced reinstatement of nicotine seeking in rats.

Results URB597 reduced cue-induced reinstatement of nicotine seeking, an effect that was reversed by the $\mathrm{CB}_{1} \mathrm{R}$ antagonist rimonabant, but not by the $\mathrm{CB}_{2} \mathrm{R}$ or PPAR $\alpha$ antagonists AM630 and MK886, respectively.

Conclusions These results indicate that URB597 reduces cueinduced reinstatement in rats through a $\mathrm{CB}_{1}$ receptordependent mechanism, and not via $\mathrm{CB}_{2} \mathrm{R}$ or PPAR $\alpha$. Since FAAH inhibition represent a novel and promising strategy for tobacco smoking cessation, dissecting how it produces its action may lead to a better understanding of the neurobiological mechanisms underlying nicotine addiction.

Keywords Nicotine Intravenous self-administration - Rats · Relapse $\cdot$ Rimonabant $\cdot$ URB597

\section{Introduction}

Tobacco dependence is a major worldwide health problem and a chronic relapsing disorder characterized by a recurrent resumption of smoking after abstinence, and nicotine is the principal component of tobacco smoke that leads to addiction in humans (Le Foll and Goldberg 2006; Rose and Corrigall 1997). Relapse to drug use is a core feature of addiction and represents a major clinical problem in addiction treatment (O'Brien 2005). In particular, discrete cues and context associated with cigarette smoking have been shown to be crucial 
contributors to the high relapse rates associated with tobacco smoking in humans by inducing a strong craving in abstinent and non-abstinent smokers (Conklin 2006; Dols et al. 2002; Niaura et al. 1998; Thewissen et al. 2005; Waters et al. 2004). Interestingly, these factors have also been reported to reinstate nicotine seeking after extinction of nicotine selfadministration in laboratory animals (Crombag et al. 2008; Stoker and Markou 2015). Despite differences with the clinical condition of relapse, reinstatement of nicotine seeking in rats is considered as a valid model of relapse to tobacco smoking in humans (Epstein et al. 2006; Shaham et al. 2003; Shiffman et al. 1996; Sinha 2001).

Thus, achieving a better understanding of the neurobiological mechanisms underlying relapse to nicotine seeking could lead to the development of novel and more efficacious pharmacotherapies for treating tobacco dependence.

Numerous studies in rodents have established that the endogenous cannabinoid system is involved in the reinforcing effect of nicotine and the relapse to nicotine seeking (Diergaarde et al. 2008; Forget et al. 2009; Le Foll et al. 2008; Scherma et al. 2008). The endogenous cannabinoid system comprises the cannabinoid receptors $\left(\mathrm{CB}_{1} \mathrm{R}\right.$ and $\mathrm{CB}_{2} \mathrm{R}$ ), the genes encoding them, and the endogenous cannabinoid ligands, primarily anandamide (AEA) and 2arachidonoylglycerol (2-AG) (Di Marzo et al. 2004; Howlett et al. 2002). It also includes the enzymes involved in their synthesis and degradation (the fatty acid amide hydrolase (FAAH) for AEA and the monoacylglycerol lipase (MAGL) for 2-AG) and the anandamide transporter (Le Foll et al. 2008; Rodriguez de Fonseca et al. 2005).

Recent studies suggest that inhibition of FAAH could be a potential therapy for nicotine addiction since the FAAH inhibitor URB597 prevents the acquisition of nicotine selfadministration and reduces nicotine reward and nicotine- and cue-induced reinstatement of nicotine seeking (Forget et al. 2009; Justinova et al. 2015; Scherma et al. 2008). It also reduces the nicotine-induced activation of dopamine neurons in the ventral tegmental area (VTA) and the subsequent elevation of dopamine outflow in the NAcc shell (ShNAc) in rats (Melis et al. 2008; Scherma et al. 2008).

The FAAH degrades not only the endocannabinoid anandamide (a partial agonist at the $\mathrm{CB}_{1} \mathrm{R}$ and $\mathrm{CB}_{2} \mathrm{R}$ ) but also several noncannabinoid members of its extended lipid family, such as oleoylethanolamide (OEA) and palmitoylethanolamide (PEA) that are agonists at the $\alpha$-subtype peroxisome proliferator-activated receptor (PPAR $\alpha)$ (Khanna and Alexander 2011; Panlilio et al. 2013).

It has been established that the effect of URB597 on nicotine's effects on dopamine neurons in the VTA is mediated by $\mathrm{CB}_{1} \mathrm{R}$ stimulation with regard to alteration of firing rate and by PPAR $\alpha$ stimulation for bursting activity (Melis et al. 2008), while URB597 reverses nicotine-induced inhibition of medium spiny neurons (MSNs) in the ShNAc via both
$\mathrm{CB}_{1} \mathrm{R}$ and PPAR $\alpha$-dependent mechanisms (Luchicchi et al. 2010). Finally, a recent study in non-human primates indicates that URB597 reduces nicotine self-administration and nicotine-induced reinstatement of nicotine seeking mostly via PPAR $\alpha$ activation while its inhibitory action on cueinduced reinstatement of nicotine seeking seems mainly PPAR $\alpha$ independent (Justinova et al. 2015). Thus, the goal of the present study was to evaluate the $\mathrm{CB}_{1} \mathrm{R}, \mathrm{CB}_{2} \mathrm{R}$, and PPAR $\alpha$ components of the effect of FAAH inhibition on cue-induced relapse to nicotine seeking in rats by blocking these receptors with the antagonists rimonabant, AM630, and MK886, respectively, during cue-induced reinstatement of nicotine-seeking sessions with or without URB597 pretreatment.

\section{Methods}

\section{Animals}

Male Long-Evans rats weighing 250-275 g were individually housed on a 12-h reverse light/dark cycle for all experiments. All the experimental procedures described in this report were carried out in accordance with the guidelines of the Canadian Council on Animal Care and were approved after being reviewed by the Institutional Animal Care Committee.

Animals were trained to lever press under the control of a one-response fixed-ratio (FR1) schedule in which each press resulted in the delivery of a $45-\mathrm{mg}$ food pellet (no cues). Once trained, each animal was surgically prepared with a chronic intravenous catheter implanted in the jugular vein and exiting between the scapulae. Surgery was performed under anesthesia induced by xylazine $(10 \mathrm{mg} / \mathrm{kg}$, intraperitoneal (IP)) and ketamine hydrochloride ( $75 \mathrm{mg} / \mathrm{kg}$, IP). Incision sites were infiltrated with the local anesthetic bupivacaine $(0.125 \%)$. Buprenorphine was given for post-operative analgesia $(0.01 \mathrm{mg} / \mathrm{kg}$, subcutaneous (SC)), and a single dose of penicillin $(30,000$ units, SC) was administered at the completion of surgical procedures. Animals were allowed to recover for a 1-week period before drug self-administration sessions were begun.

\section{Drugs}

(-)Nicotine hydrogen tartrate (Sigma-Aldrich, St. Louis, MO, USA) dissolved in saline was $\mathrm{pH}$ adjusted to $7.0( \pm 0.2)$ and filtered through a $0.22-\mathrm{mm}$ syringe filter (Fisher Scientific, Pittsburgh, PA, USA). Nicotine doses are reported as a free base. Nicotine was administered intravenously (IV) in a volume of $100 \mu \mathrm{l} / \mathrm{kg} /$ injection. Doses, volumes of injection, vehicles, and pretreatment times for URB597 (Kadmus Pharmaceuticals), rimonabant (SR-141716A; National Institute on Drug Abuse), AM630 (Tocris Bioscience, 
Missouri USA), and MK886 (Tocris Bioscience, Missouri USA) are presented in Table 1. All drugs were administered IP.

\section{Self-administration and extinction procedures}

Training procedures for nicotine self-administration were similar to those previously reported (Forget et al. 2010a, b).

Session start was signaled by the illumination of a houselight and session duration was $60 \mathrm{~min}$. Responding on the active lever resulted in rapid delivery $(1 \mathrm{~s})$ of nicotine (30 $\mu \mathrm{g} / \mathrm{kg} /$ infusion) and a 60 -s time-out period (during which house-light turned off and cue light above active lever illuminated) when schedule requirements were met. Responding on the other (inactive) lever was recorded but had no programmed consequences. Animals were trained for eight sessions under an FR schedule of reinforcement with FR requirements gradually increasing from FR1 to final FR5 (i.e., every 5 th lever press produced an injection of nicotine). After a minimum of ten sessions under an FR5 schedule, rats were considered to have acquired stable SA when (1) the ratio of active/inactive lever presses was $\geq 2: 1$; rats obtained $\geq 10$ infusions/session, and (3) $<20 \%$ variation in infusions/session for two consecutive sessions. This was followed by an extinction phase during which responses on both the active and inactive lever were recorded but had no consequences. The criterion for extinction were (1) $<20 \%$ variation in active lever presses/ session over two consecutive sessions; (2) $<20$ active lever presses or $<15 \%$ of active lever presses compared to the average of the last three SA sessions, whichever was lower.

\section{Cue-induced reinstatement of nicotine seeking}

Reinstatement tests were conducted under conditions identical to that of extinction, except (1) a single presentation of the visual light cue (light above the active lever turned on and house light off for $60 \mathrm{~s}$ ) was delivered non-contingently immediately at the start of the session and (2) responses on the active lever (under an FR-5 schedule) resulted in contingent presentation of the cues (light above the active lever on and house light off for $60 \mathrm{~s}$ ). Responses on the inactive lever were recorded but were without consequence. Drug treatments were administered IP as presented in Table 1. Each drugs (rimonabant, AM630, MK886) was tested in a separate group of animals ( $n=13$ for rimonabant, $n=8$ for AM630, and $n=8$ for MK886). Thus, each animal was been tested four times for cue-induced reinstatement (vehicule/vehicule, URB597/ vehicule, vehicule/antagonist (rimonabant, AM630, or MK886), and URB597/antagonist (rimonabant, AM630, or MK886)) in a latin-square design with at least three extinction sessions between each test and a display of stable extinction over two consecutive sessions.

\section{Data analysis}

Response rate data were analyzed. Data (lever presses) were subjected to a two-way repeated-measures (RM) ANOVAs, with lever and condition as within-subject factors, and followed when appropriate by post hoc LSD tests for multiple comparisons. Cue-induced reinstatement responding under vehicle treatments between the three experiments was subjected to a one-way ANOVA. Changes were considered significant when $p<0.05$.

\section{Results}

\section{Cue-induced reinstatement between experimental groups}

The one-way ANOVA performed on active lever presses during cue-induced reinstatement under vehicle treatments (vehicle + vehicle condition) demonstrated no significant effect of experimental group $\left(F_{2,25}=0.10, p>0.05\right)$, demonstrating that reinstatement levels between experimental groups (rimonabant, AM630, and MK886 groups) were not significantly different.

The mean number of nicotine infusions received during the last two self-administration sessions under FR5 schedule of reinforcement prior to extinction was $16.8 \pm 1.6$ for the rimonabant group, $16.1 \pm 0.6$ for the AM630 group, and $15 \pm 1.7$ for the MK886 group.

\section{Rimonabant reverses URB597 attenuation of cue-induced reinstatement}

The two-way RM ANOVA $(n=13)$ demonstrated a significant effect of lever $\left(F_{1,24}=26.21, p<0.0001\right)$, condition $\left(F_{4}\right.$,

Table 1 Doses, volumes of injection, vehicles, and pretreatment times for drug treatments

\begin{tabular}{lllll}
\hline Drug & Dose $(\mathrm{mg} / \mathrm{kg})$ & Volume $(\mathrm{ml} / \mathrm{kg})$ & Vehicle & Pretreatment time (min) \\
\hline URB597 & 0.3 & 2 & $20 \%$ DMSO, 80 \% saline & 30 \\
Rimonabant & 0.15 & 1 & $0.3 \%$ Tween $80,99.7 \%$ saline & 60 \\
AM630 & 5 & 2 & $10 \%$ DMSO, 10 \% Tween 80, 80 \% distilled water & 60 \\
MK886 & 1 & 1 & $10 \%$ DMSO, 90\% saline & 60 \\
\hline
\end{tabular}

DMSO dimethylsulfoxide 
$\left.{ }_{96}=8.32, p<0.00001\right)$ and interaction $\left(F_{4.96}=4.34, p<0.01\right.$; Fig. 1a). LSD post hoc comparisons demonstrated no significant differences in inactive lever responding between conditions. A significant difference was observed on active lever responding between baseline ( $<20$ active lever presses with less than $20 \%$ variation over two consecutive sessions) and cue-induced reinstatement with vehicle + vehicle administration $(p<0.00001)$. Vehicle + vehicle was significantly different from vehicle + URB597 $(p<0.01)$ but not rimonabant + vehicle or rimonabant + URB597. Vehicle + URB597 was significantly different from rimonabant+URB597 $(p<0.05)$.

These results indicate that URB597 reduces cueinduced reinstatement of nicotine seeking and that this effect is reversed by rimonabant at $0.15 \mathrm{mg} / \mathrm{kg}$, which has no effect on its own on cue-induced reinstatement of nicotine seeking.

\section{AM630 has no effect on URB597 attenuation of cue-induced reinstatement}

The two-way RM ANOVA $(n=8)$ demonstrated a significant effect of lever $\left(F_{1,14}=19.77, p<0.001\right)$, condition $\left(F_{4}\right.$, $\left.{ }_{56}=4.67, p<0.01\right)$, and interaction $\left(F_{4,56}=2.99, p<0.05\right.$; Fig. 1b). LSD post hoc comparisons demonstrated no significant differences in inactive lever responding between conditions. For active lever responding a significant difference was observed between baseline and vehicle + vehicle $(p<0.0001)$. Vehicle + vehicle treatment was significantly different from vehicle + URB597 $(p<0.01)$ and AM630+ URB597 $(p<0.05)$ but not AM630+ vehicle. Vehicle+URB597 was not significantly different from AM630+URB597, demonstrating that AM630 had no effect on the URB597 attenuation of cue-induced reinstatement of nicotine seeking.

\section{MK886 has no effect on URB597 attenuation of cue-induced reinstatement}

The two-way RM ANOVA $(n=8)$ demonstrated a significant effect of lever $\left(F_{1,14}=47.32, p<0.00001\right)$, condition $\left(F_{4,56}=6.89, p<0.001\right)$, and interaction $\left(F_{4,56}=6.09\right.$, $p<0.001$; Fig. 1c). LSD post hoc comparisons demonstrated no significant differences in inactive lever responding between conditions. For active lever responding, a significant difference was observed between baseline and vehicle + vehicle $(p<0.00001)$. Vehicle + vehicle treatment was significantly different from vehicle + URB597 $(p<0.01)$ and MK886 + URB597 $(p<0.0001)$ but not MK886+ vehicle. Vehicle + URB597 was not significantly different from MK886+URB597, demonstrating that MK886 had no effect on the URB597 attenuation of cue-induced reinstatement of nicotine seeking.

\section{Discussion}

In this study, $\mathrm{CB}_{1} \mathrm{R}$ blockade by the selective $\mathrm{CB}_{1}$ antagonist rimonabant (Boyd and Fremming 2005) completely reversed the ability of URB597 to attenuate cue-induced reinstatement of nicotine seeking in rats trained to self-administer nicotine, while antagonism of $\mathrm{CB}_{2} \mathrm{R}$ or PPAR $\alpha$ by $\mathrm{AM} 630$ and MK886, respectively, had no such effect. These results suggest that the action of FAAH inhibition on cue-induced relapse to nicotine seeking is mainly $\mathrm{CB}_{1}$-dependent and $\mathrm{CB}_{2} /$ PPAR $\alpha$-independent.

We used URB597 at the dose of $0.3 \mathrm{mg} / \mathrm{kg}$ in the present study because it has previously been shown to produce a maximal effect on cue-induced reinstatement of nicotine seeking

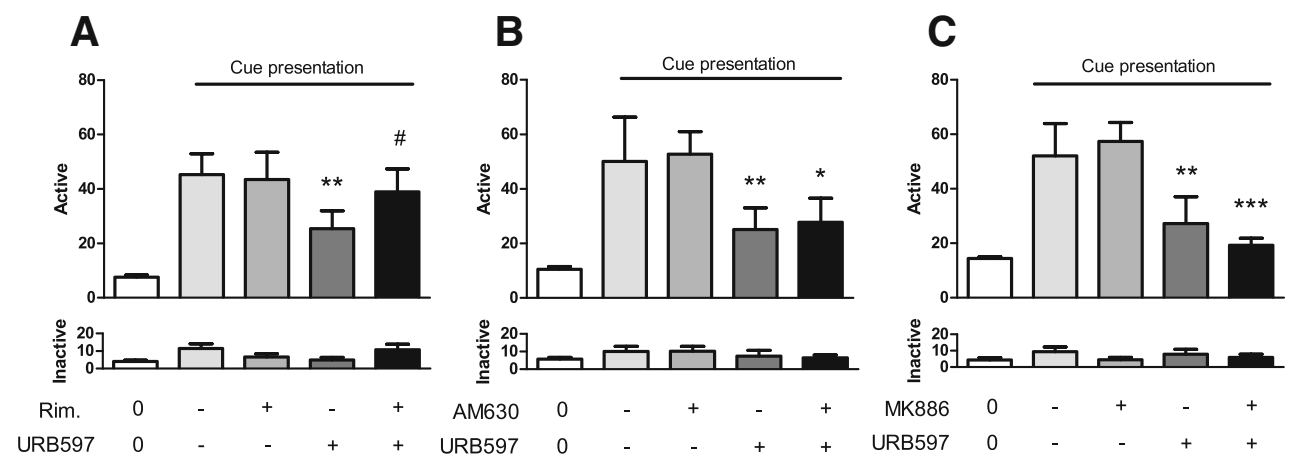

Fig. 1 Effect of pretreatment with a rimonabant $(0.15 \mathrm{mg} / \mathrm{kg} ; n=13), \mathbf{b}$ AM630 $(5 \mathrm{mg} / \mathrm{kg} ; n=8)$, or c MK886 $(1 \mathrm{mg} / \mathrm{kg} ; n=8)$ on cue-induced reinstatement of nicotine-seeking both with and without URB597 pretreatment $(0.3 \mathrm{mg} / \mathrm{kg})$. Cue presentation involved a light cue above the active lever being presented ( $60 \mathrm{~s})$ non-contingently at the start of the session and contingently thereafter under a FR-5 schedule of reinforcement. Data are expressed as means $( \pm$ SEM) of the number of lever presses during baseline extinction conditions (white bar) or during cure-reinstatement conditions. "+" indicates the respective drug being administered, "-" indicates the vehicle for the respective drug being administered, and " 0 " indicates saline injections being administered (baseline extinction). ${ }^{*} p<0.05,{ }^{* *} p<0.01,{ }^{*} p<0.0001$ vs. vehicle + vehicle; ${ }^{*} p<0.05$ vs. vehicle + URB597; LSD multiple comparisons following two-way repeated-measures ANOVAs 
in rats (Forget et al. 2009) and to induce a full, fast, and longlasting inhibition of FAAH (Kathuria et al. 2003).

It is known that rimonabant itself has an attenuating effect on cue-induced reinstatement of nicotine seeking (Forget et al. 2009), representing a potential confounding factor for the use of this $\mathrm{CB}_{1} \mathrm{R}$ antagonist to evaluate $\mathrm{CB}_{1} \mathrm{R}$ dependency on this behavior. However, we chose a low dose of rimonabant that by itself clearly has no effect on cue-induced reinstatement of nicotine seeking, ruling out this potential problem.

The lack of effect of $\mathrm{CB}_{2} \mathrm{R}$ and PPAR $\alpha$ antagonism is unlikely due to the use of doses too low to block the receptors, considering the high selectivity, potency, and affinity of AM630 and MK886 for these receptors (Kehrer et al. 2001; Mukherjee et al. 2004). In addition, we used a high dose of AM630 (Gamaleddin et al. 2012b; Lopez Rodriguez et al. 2011) and a dose of MK886 that has been shown to fully antagonize the enhancing effect of URB597 on memory acquisition in rats (Mazzola et al. 2009) and to reverse the inhibitory effect of URB597 on nicotine self-administration and nicotine-induced reinstatement of nicotine seeking in monkeys (Justinova et al. 2015).

The result that URB597 acts on cue-induced reinstatement of nicotine seeking via stimulation of $\mathrm{CB}_{1}$ receptors may seem surprising considering the fact that direct stimulation of these receptors by a $\mathrm{CB}_{1} \mathrm{R}$ agonist potentiate, rather than inhibit, this behavior (Gamaleddin et al. 2012a). However, FAAH inhibition differs from exogenous $\mathrm{CB}_{1}$ stimulation as it results in an increase of anandamide levels only in brain areas in which the release of endogenous cannabinoids have been triggered by a specific stimulus. Thus, URB597 can produce a three- to fivefold increase in anandamide brain levels, yet without producing the effects classically observed with the administration of exogenous cannabinoids (Piomelli et al. 2006; Rodriguez de Fonseca et al. 2005; Justinova et al. 2008) and can counteract nicotine-induced stimulation of DA neurons in the VTA and DA release in the ShNAcc, two effects that can be involved in relapse to drugs seeking (Melis et al. 2008; Scherma et al. 2008).

Interestingly, URB597 blocks the enhancing effect of nicotine on the firing rate of dopaminergic neurons in the VTA via a $\mathrm{CB}_{1}$-dependant mechanism, while blocking nicotine's effect on the burst activity of the same neurons via a PPAR $\alpha$ -dependent mechanism. Thus, it is possible that exposure to cues previously paired with nicotine enhances the firing rate of mesolimbic dopaminergic neurons but not their bursting activity. This would explain why, in our study, the effect of URB597 on cue-induced nicotine seeking is mediated by $\mathrm{CB}_{1}$ and not PPAR $\alpha$ receptors.

URB597 also reduces nicotine-induced reinstatement in rats (Forget et al. 2009; Scherma et al. 2008), an effect that might be partially dependent upon PPAR $\alpha$ receptors stimulation (Justinova et al. 2015). Thus, the mechanism of action of
URB597 seems to depend on the modalities that induce reinstatement of nicotine seeking.

In conclusion, our study confirms the ability of FAAH inhibition by URB597 to attenuate cue-induced reinstatement of nicotine seeking, and the absence of reversal by the PPAR $\alpha$ receptors antagonist MK886 (Justinova et al. 2015). We further established that this effect is $\mathrm{CB}_{1} \mathrm{R}$ - and not $\mathrm{CB}_{2} \mathrm{R}$-dependent. More investigations will be needed to determine if our findings with URB597 can be extended to other FAAH inhibitors.

As inhibition of FAAH represents a novel and promising strategy to treat tobacco addiction, understanding its mechanism of action is important for a clearer view of this pathology.

Acknowledgments We thank A. Pushparaj for his help during the experiments and comments on the manuscript. The experiments comply with the current laws of Canada.

\section{Compliance with ethical standards}

Funding This work was supported by a grant from the Heart and Stroke Foundation no. NA 6901.

Conflict of interest The authors declare that they have no conflict of interest.

\section{References}

Boyd ST, Fremming BA (2005) Rimonabant-a selective CB1 antagonist. Ann Pharmacother 39:684-90

Conklin CA (2006) Environments as cues to smoke: implications for human extinction-based research and treatment. Exp Clin Psychopharmacol 14:12-9

Crombag HS, Bossert JM, Koya E, Shaham Y (2008) Review. Contextinduced relapse to drug seeking: a review. Philos Trans R Soc Lond Ser B Biol Sci 363:3233-43

Di Marzo V, Bifulco M, De Petrocellis L (2004) The endocannabinoid system and its therapeutic exploitation. Nat Rev Drug Discov 3: $771-84$

Diergaarde L, de Vries W, Raaso H, Schoffelmeer AN, De Vries TJ (2008) Contextual renewal of nicotine seeking in rats and its suppression by the cannabinoid-1 receptor antagonist Rimonabant (SR141716A). Neuropharmacology 55:712-6

Dols M, van den Hout M, Kindt M, Willems B (2002) The urge to smoke depends on the expectation of smoking. Addiction 97:87-93

Epstein DH, Preston KL, Stewart J, Shaham Y (2006) Toward a model of drug relapse: an assessment of the validity of the reinstatement procedure. Psychopharmacology 189:1-16

Forget B, Coen KM, Le Foll B (2009) Inhibition of fatty acid amide hydrolase reduces reinstatement of nicotine seeking but not break point for nicotine self-administration-comparison with $\mathrm{CB}(1)$ receptor blockade. Psychopharmacology 205:613-24

Forget B, Pushparaj A, Le Foll B (2010a) Granular insular cortex inactivation as a novel therapeutic strategy for nicotine addiction. Biol Psychiatry 68:265-71

Forget B, Wertheim C, Mascia P, Pushparaj A, Goldberg SR, Le Foll B (2010b) Noradrenergic alpha1 receptors as a novel target for the treatment of nicotine addiction. Neuropsychopharmacology 35 : $1751-60$ 
Gamaleddin I, Wertheim C, Zhu AZ, Coen KM, Vemuri K, Makryannis A, Goldberg SR, Le Foll B (2012a) Cannabinoid receptor stimulation increases motivation for nicotine and nicotine seeking. Addict Biol 17:47-61

Gamaleddin I, Zvonok A, Makriyannis A, Goldberg SR, Le Foll B (2012b) Effects of a selective cannabinoid CB2 agonist and antagonist on intravenous nicotine self administration and reinstatement of nicotine seeking. PLoS ONE 7:e29900

Howlett AC, Barth F, Bonner TI, Cabral G, Casellas P, Devane WA, Felder CC, Herkenham M, Mackie K, Martin BR, Mechoulam R, Pertwee RG (2002) International Union of Pharmacology. XXVII. Classification of cannabinoid receptors. Pharmacol Rev 54:161-202 Justinova Z, Mangieri RA, Bortolato M, Chefer SI, Mukhin AG, Clapper JR, King AR, Redhi GH, Yasar S, Piomelli D, Goldberg SR (2008) Fatty acid amide hydrolase inhibition heightens anandamide signaling without producing reinforcing effects in primates. Biol Psychiatry 64:930-7

Justinova Z, Panlilio LV, Moreno-Sanz G, Redhi GH, Auber A, Secci ME, Mascia P, Bandiera T, Armirotti A, Bertorelli R, Chefer SI, Barnes C, Yasar S, Piomelli D, Goldberg SR (2015) Effects of fatty acid amide hydrolase (FAAH) inhibitors in non-human primate models of nicotine reward and relapse. Neuropsychopharmacology 40:2185-97

Kathuria S, Gaetani S, Fegley D, Valino F, Duranti A, Tontini A, Mor M, Tarzia G, La Rana G, Calignano A, Giustino A, Tattoli M, Palmery M, Cuomo V, Piomelli D (2003) Modulation of anxiety through blockade of anandamide hydrolysis. Nat Med 9:76-81

Kehrer JP, Biswal SS, La E, Thuillier P, Datta K, Fischer SM, Vanden Heuvel JP (2001) Inhibition of peroxisome-proliferator-activated receptor (PPAR)alpha by MK886. Biochem J 356:899-906

Khanna IK, Alexander CW (2011) Fatty acid amide hydrolase inhibitors-progress and potential. CNS Neurol Dis Drug Targets 10: $545-58$

Le Foll B, Forget B, Aubin HJ, Goldberg SR (2008) Blocking cannabinoid $\mathrm{CB} 1$ receptors for the treatment of nicotine dependence: insights from pre-clinical and clinical studies. Addict Biol 13:239-52

Le Foll B, Goldberg SR (2006) Nicotine as a typical drug of abuse in experimental animals and humans. Psychopharmacology 184: 367-81

Lopez Rodriguez AB, Mateos Vicente B, Romero-Zerbo SY, RodriguezRodriguez N, Bellini MJ, Rodriguez de Fonseca F, Bermudez-Silva FJ, Azcoitia I, Garcia-Segura LM, Viveros MP (2011) Estradiol decreases cortical reactive astrogliosis after brain injury by a mechanism involving cannabinoid receptors. Cereb Cortex 21:2046-55

Luchicchi A, Lecca S, Carta S, Pillolla G, Muntoni AL, Yasar S, Goldberg SR, Pistis M (2010) Effects of fatty acid amide hydrolase inhibition on neuronal responses to nicotine, cocaine and morphine in the nucleus accumbens shell and ventral tegmental area: involvement of PPAR-alpha nuclear receptors. Addict Biol 15:277-88

Mazzola C, Medalie J, Scherma M, Panlilio LV, Solinas M, Tanda G, Drago F, Cadet JL, Goldberg SR, Yasar S (2009) Fatty acid amide hydrolase (FAAH) inhibition enhances memory acquisition through activation of PPAR-alpha nuclear receptors. Learn Mem 16:332-7
Melis M, Pillolla G, Luchicchi A, Muntoni AL, Yasar S, Goldberg SR, Pistis M (2008) Endogenous fatty acid ethanolamides suppress nicotine-induced activation of mesolimbic dopamine neurons through nuclear receptors. J Neurosci 28:13985-94

Mukherjee S, Adams M, Whiteaker K, Daza A, Kage K, Cassar S, Meyer M, Yao BB (2004) Species comparison and pharmacological characterization of rat and human CB2 cannabinoid receptors. Eur J Pharmacol 505:1-9

Niaura R, Shadel WG, Abrams DB, Monti PM, Rohsenow DJ, Sirota A (1998) Individual differences in cue reactivity among smokers trying to quit: effects of gender and cue type. Addict Behav 23:209-24

O'Brien CP (2005) Anticraving medications for relapse prevention: a possible new class of psychoactive medications. Am J Psychiatry $162: 1423-31$

Panlilio LV, Justinova Z, Goldberg SR (2013) Inhibition of FAAH and activation of PPAR: new approaches to the treatment of cognitive dysfunction and drug addiction. Pharmacol Ther 138:84-102

Piomelli D, Tarzia G, Duranti A, Tontini A, Mor M, Compton TR, Dasse O, Monaghan EP, Parrott JA, Putman D (2006) Pharmacological profile of the selective FAAH inhibitor KDS-4103 (URB597). CNS Drug Rev 12:21-38

Rodriguez de Fonseca F, Del Arco I, Bermudez-Silva FJ, Bilbao A, Cippitelli A, Navarro M (2005) The endocannabinoid system: physiology and pharmacology. Alcohol Alcohol 40:2-14

Rose JE, Corrigall WA (1997) Nicotine self-administration in animals and humans: similarities and differences. Psychopharmacology 130:28-40

Scherma M, Panlilio LV, Fadda P, Fattore L, Gamaleddin I, Le Foll B, Justinova Z, Mikics E, Haller J, Medalie J, Stroik J, Barnes C, Yasar S, Tanda G, Piomelli D, Fratta W, Goldberg SR (2008) Inhibition of anandamide hydrolysis by cyclohexyl carbamic acid 3'-carbamoyl-3-yl ester (URB597) reverses abuse-related behavioral and neurochemical effects of nicotine in rats. $\mathrm{J}$ Pharmacol Exp Ther 327:482-90

Shaham Y, Shalev U, Lu L, De Wit H, Stewart J (2003) The reinstatement model of drug relapse: history, methodology and major findings. Psychopharmacology 168:3-20

Shiffman S, Hickcox M, Paty JA, Gnys M, Kassel JD, Richards TJ (1996) Progression from a smoking lapse to relapse: prediction from abstinence violation effects, nicotine dependence, and lapse characteristics. J Consult Clin Psychol 64:993-1002

Sinha R (2001) How does stress increase risk of drug abuse and relapse? Psychopharmacology 158:343-59

Stoker AK, Markou A (2015) Neurobiological bases of cue- and nicotineinduced reinstatement of nicotine seeking: implications for the development of smoking cessation medications. Curr Top Behav Neurosci 24:125-54

Thewissen R, van den Hout M, Havermans RC, Jansen A (2005) Context-dependency of cue-elicited urge to smoke. Addiction 100: 387-96

Waters AJ, Shiffman S, Sayette MA, Paty JA, Gwaltney CJ, Balabanis MH (2004) Cue-provoked craving and nicotine replacement therapy in smoking cessation. J Consult Clin Psychol 72:1136-43 